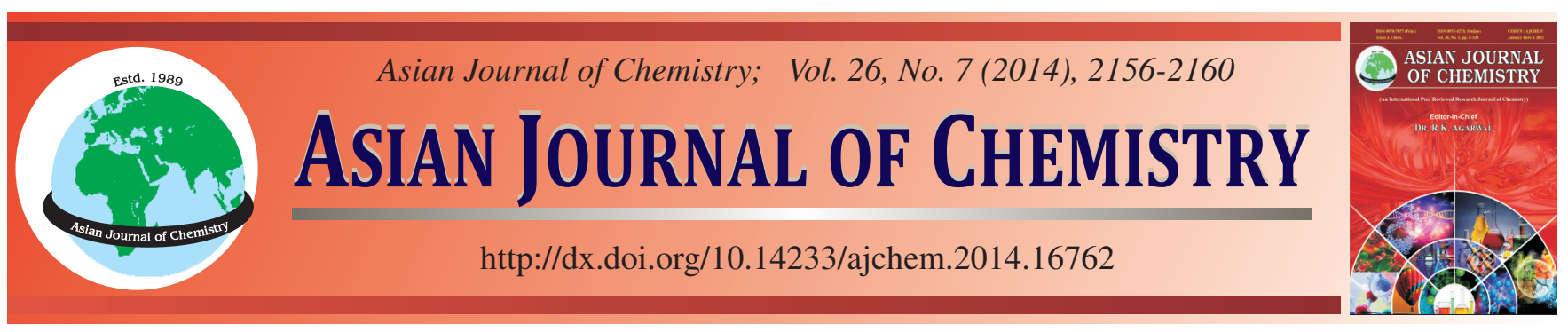

\title{
Determination of Fatty Acid and Essential Oil Constituents and Biological Activities on Ranunculus pedatus Subsp. pedatus
}

\author{
T. Erdogan ${ }^{1, *}$, T. Gonenc ${ }^{1}$, B. DemirCI ${ }^{2}$, B. KIVÇAK ${ }^{1}$ and K.H.C. BASER ${ }^{2,3,4}$
}

\begin{abstract}
${ }^{1}$ Department of Pharmacognosy, Faculty of Pharmacy, Ege University, Bornova, Izmir, Turkey ${ }^{2}$ Department of Pharmacognosy, Faculty of Pharmacy, Anadolu University, Eskisehir, Turkey

${ }^{3}$ Botany and Microbiology Department, College of Science, King Saud University, Riyadh, Saudi Arabia ${ }^{4}$ Technology Transfer Office, Bahcesehir University, Istanbul, Turkey
\end{abstract}

*Corresponding author: Fax: +90 232 3885258; Tel: +90 232 3113965; E-mail: tugce.fafal@ege.edu.tr; tugceerfa@hotmail.com

\begin{abstract}
In this study, the fatty-acid profile, essential-oil composition and cytotoxic and antioxidant activities of the aerial parts of Ranunculus pedatus Waldst. \& Kit. subsp. pedatus have been examined. Linoleic acid (24.47\%) and palmitoleic acid (18.94\%) were identified as major components by GC-FID and GC/MS analysis. Unsaturated fatty acids were found in higher amounts than saturated fatty acids. The essential oil composition was also analyzed by GC and GC/MS and 29 components were characterized. Protoanemonin (14.3\%), phytol $(13.7 \%), \alpha$-bisabolol (7.9 \%), (Z)-3-hexenol (7.8\%) and octanol (6.7 \%) were determined as the main constituents of the essential oil. Ethanol and chloroform extracts were investigated for the cytotoxic activity against PC3, HeLa and Vero human cancer cell lines and both of the extracts were found to be effective on $\mathrm{HeLa}$. The $\mathrm{IC}_{50}$ values were determined as 47 and $78.4 \mathrm{mg} / \mathrm{mL}$ for methanol and chloroform extracts respectively. Antioxidant activity of chloroform and ethanol extracts were evaluated by DPPH assay. The total phenolics and flavonoid contents of the extracts were determined by Folin-Ciocalteau and aluminium chloride methods, respectively. The ethanol extract was found to possess $67.54 \%$ DPPH inhibition. The results obtained in the antioxidant activity assay were in positive correlation with the total phenolics and flavonoid contents of the extracts.
\end{abstract}

Keywords: Ranunculus pedatus subsp. pedatus, Fatty acid, Essential oil, Cytotoxic activity, Antioxidant activity.

\section{INTRODUCTION}

Ranunculus genus with the greatest diversity within the family Ranunculaceae is represented by 600 species $^{1}$. There are 84 wild-growing species belonging to this genus in Turkey ${ }^{1-3}$. Ranunculus species have been used in traditional medicine for wound healing ${ }^{4}$, antihemoroidal ${ }^{5-7}$, maturation of abcess ${ }^{8,9}$, against rheumatism ${ }^{8}$ and for the treatment of tuberculosis ${ }^{10}$.

This genus have previously been investigated for its flavonoids $^{11-15}$, saponins ${ }^{16,17}$, alkaloids ${ }^{18,19}$, fatty and organic acids ${ }^{20-22}$. In previous studies, Ranunculus species have been shown to possess antimicrobial ${ }^{23-25}$, cytotoxic ${ }^{15}$, anti-inflammatory ${ }^{14,26-28}$, antioxidant ${ }^{24,29,30}$ and antiprotozoal ${ }^{31}$.

The aim of the present study is to evaluate the fatty acid, essential oil composition, cytotoxic and antioxidant activities of Ranunculus pedatus subp. pedatus growing wild in Manisa, Turkey. The essential oil composition of $R$. arvensis and $R$. constantinapolitanus $^{32}$ and antioxidant activities of the extracts of $R$. marginatus var. trachycarpus and $R$. sprunerianus previously reported $^{24}$. To the best of our knowledge, no previous work has been reported on the essential oil and fatty acid composition and biological activities of $R$. pedatus subsp. pedatus.

\section{EXPERIMENTAL}

R. pedatus Waldst. \& Kit. subsp. pedatus (Ranunculaceae) was collected from Manisa on May 2005. The plant was identified by M. Ali Önür from Ege University, Faculty of Pharmacy, Department of Pharmacognosy and a voucher specimen (No. 1364) is deposited in Herbarium of the Ege University, Faculty of Pharmacy.

Fatty acid analysis: The dried and powdered aerial parts of the plant material $(40 \mathrm{~g})$ have been extracted by petroleum ether $(250 \mathrm{~mL})$ for $6 \mathrm{~h}$ at $60{ }^{\circ} \mathrm{C}$ by Soxhlet extractor. The solvent was evaporated by a rotary evaporator. The obtained oil was esterified to determine the fatty acid composition. The extraction yield was found as $1.13 \%$.

Preparation of fatty acid methyl esters (FAMEs): The fatty acids were esterified into methyl esters by saponification with $0.5 \mathrm{~N}$ methanolic sodium hydroxide and transesterified with $14 \%(\mathrm{v} / \mathrm{v})$ boron trifluoride $\left(\mathrm{BF}_{3}\right)$ in methanol under reflux ${ }^{33}$.

GC conditions: Fatty acid methyl esters (FAMEs) were analyzed on a HP (Hewlett Packard) Agilent $6890 \mathrm{~N}$ model gas chromatograph (GC), equipped with a flame ionization detector (FID) and fitted to a Supelco SP-2380 Fased Silica 
capillary column $(60 \mathrm{~m}, 0.25 \mathrm{~mm}$ i.d. and $0.2 \mu \mathrm{m})$. Injector and detector temperatures were set at 250 and $260{ }^{\circ} \mathrm{C}$, respectively. The oven was programmed at an initial temperature of $140^{\circ} \mathrm{C}$ and an initial time of $5 \mathrm{~min}$. Thereafter the temperature was increased up to $240{ }^{\circ} \mathrm{C}$ at a rate of $3{ }^{\circ} \mathrm{C} \mathrm{min}{ }^{-1}$. The total run time was $41.33 \mathrm{~min}$. Helium was used as the carrier gas (1 $\left.\mathrm{mL} \mathrm{min}^{-1}\right)$. Identification of fatty acids was carried out by comparing sample FAME peak relative retention times. The results were expressed as FID response area in the relative percentages. Each reported result is given as the average value of three GC analyses. The results are offered as means \pm S.D.

Essential oil analysis: Hydrodistillation of the air-dried plant material for $3 \mathrm{~h}$ using a Clevenger-type apparatus afforded a yellow essential oil. The obtained essential oil was stored at $+4{ }^{\circ} \mathrm{C}$ until use. The total yield was $0.05 \%$ (w/w).

GC and GC/MS conditions: The GC/MS analysis were carried out with an Agilent 5975 GC-MSD system. Innowax FSC column ( $60 \mathrm{~m} \times 0.25 \mathrm{~mm}, 0.25 \mathrm{~mm}$ film thickness $)$ was used with helium as carrier gas $(0.8 \mathrm{~mL} / \mathrm{min})$. GC oven temperature was kept at $60^{\circ} \mathrm{C}$ for $10 \mathrm{~min}$ and programmed to $220^{\circ} \mathrm{C}$ at a rate of $4{ }^{\circ} \mathrm{C} / \mathrm{min}$ and kept constant at $220^{\circ} \mathrm{C}$ for $10 \mathrm{~min}$ and then programmed to $240{ }^{\circ} \mathrm{C}$ at a rate of $1{ }^{\circ} \mathrm{C} / \mathrm{min}$. Split ratio was adjusted at 40:1. The injector temperature was set at $250{ }^{\circ} \mathrm{C}$. Mass spectra were recorded at $70 \mathrm{eV}$. Mass range was from $m / z, 35$ to 450 .

The GC analysis was carried out using an Agilent 6890N GC system. FID detector temperature was $300{ }^{\circ} \mathrm{C}$. To obtain the same elution order with GC-MS, simultaneous auto-injection was done on a duplicate of the same column applying the same operational conditions. Relative percentage amounts of the separated compounds were calculated from FID chromatograms. The analysis results are given in Table-1.

Identification of components: Identification of the essential oil components were carried out by comparison of their relative retention times with those of authentic samples or by comparison of their relative retention index (RRI) to series of $n$-alkanes. Computer matching against commercial (Wiley GC/ MS Library, Adams Library, MassFinder 3 Library $)^{34,35}$ and in-house "Baser Library of Essential Oil Constituents" built up by genuine compounds and components of known oils, as well as MS literature data ${ }^{36,37}$ was used for the identification.

\section{Biological activity assays}

Preparation of plant extracts: Chloroform and ethanol extracts were separately prepared from $40 \mathrm{~g}$ batches of the air-dried and powdered plant materials by extracting with $400 \mathrm{~mL}$ solvent at room temperature under stirring for $24 \mathrm{~h}$. Then the solvents were evaporated to dryness in vacuo $\left(60^{\circ} \mathrm{C}\right)$. The yields of chloroform and ethanol extracts of $R$. pedatus subsp. pedatus were 1.06 and $2.12 \%$, respectively. All the extracts were stored at $-20{ }^{\circ} \mathrm{C}$.

\section{Cytotoxic activity assay}

Cell lines and culture medium: PC3, Vero and HeLa cell lines were obtained from ATCC. All cells were cultivated in a humidified incubator at $37^{\circ} \mathrm{C}$ with $5 \% \mathrm{CO}_{2}$. Cells were cultured in DMEM supplemented with L-glutamine ( $2 \mathrm{mmol} /$ L) and $10 \%$ fetal bovine serum. All the tissue culture reagents were purchased from Biological Industries (Israel).
Determination of cell viability by Real-Time Cell Analyzer (RTCA): Cells were grown and expanded in $100 \mathrm{~mm}$ tissue culture dishes. After reaching 60-80\% confluence, cells were washed with PBS and detached from the flasks by trypsin/ EDTA treatment. Meanwhile, $100 \mu \mathrm{L}$ of cell culture media at room temperature was added into each well of E-plate 96 and background of E-plate was measured. To determine the optimum cell number, 5000 cells/well were seeded for each cell line. After $0.5 \mathrm{~h}$ of incubation at room temperature, E-plates were placed into the Real-Time Cell Analyzer MP (RTCA) station. Cells were grown and impedance was measured every $0.5 \mathrm{~h}$ as the cell index $(\mathrm{CI})$ value. To determine the effect of test extracts, optimum number of cells (PC3:7500, HeLa: 7500 and Vero: 7500 ) for each cell line were seeded. After 16-24 h cells were exposed to test extracts at different concentrations $(25,100$, 25,500 and $1000 \mu \mathrm{g} / \mathrm{mL}$ ). CI values were monitored every $2 \mathrm{~min}$ for $2 \mathrm{~h}$ to visualize the fast drug response and then every $0.5 \mathrm{~h}$ for the late drug response. The electrial impedance was measured by RTCA software of the xCELLingence system as a dimensionless parameter termed CI. All the measurements were done at least in triplets and $\mathrm{IC}_{50}$ values were determined using RTCA software.

DPPH radical scavenging assay: DPPH (1,1-diphenyl2-picrylhydrazyl; Fluka, Steinheim, Germany) radical scavenging activity of $R$. pedatus subp. pedatus was evaluated according to a modified version of the method described by Gezer et al. ${ }^{38}$. One thousand $\mu \mathrm{L}$ of $1 \mathrm{mg} / \mathrm{mL}$ concentration of the extracts in ethanol and chloroform were added to $4 \mathrm{~mL}$ of $0.004 \%$ methanol solution of DPPH. After a $0.5 \mathrm{~h}$ incubation period at room temperature, the absorbance was read against a blank at $517 \mathrm{~nm}$. Inhibition of free radical by DPPH was calculated by the following equation:

$$
\mathrm{I} \%=\left[\left(\mathrm{A}_{\mathrm{b}}-\mathrm{A}_{\mathrm{s}}\right) / \mathrm{A}_{\mathrm{b}}\right] \times 100
$$

where $A_{b}$ is the absorbance of the control reaction and $A_{s}$ is the absorbance of the test sample. $\alpha$-tocopherol (TOC) was used for comparison. Tests were carried out in triplicate.

Determination of total phenolic and flavonoid contents: Total phenolic constituents was determined by using the FolinCiocalteu method $^{39} .0 .1 \mathrm{~mL}$ of the extracts $(0.5$ and $1 \mathrm{mg} / \mathrm{mL})$ were mixed with $2.8 \mathrm{~mL}$ deionized water. This solution was mixed with $2 \mathrm{~mL} 2 \%$ sodium carbonate and $0.1 \mathrm{~mL}$ of $0.1 \mathrm{~N}$ Folin-Ciocalteu reagent. After incubation at room temperature for $0.5 \mathrm{~h}$ the absorbance of the mixture was measured at $750 \mathrm{~nm}$ against a deionized water blank on a UNIQCAM 8625 UV/ visible spectrophotometer. Gallic acid was chosen as a standart. The data expressed as miligram gallic acid equivalents.

Total flavonoid content was determined by the aluminium chloride colorimetric method described by Chang et al. ${ }^{40}$ $0.5 \mathrm{~mL}$ of the extracts $(0.5$ and $1 \mathrm{mg} / \mathrm{mL})$ were mixed with $1.5 \mathrm{~mL}$ of ethanol, $0.1 \mathrm{~mL}$ of $10 \%$ aluminium chloride and $2.8 \mathrm{~mL}$ of distilled water. The mixture was kept at room temperature for $0.5 \mathrm{~h}$ and the absorbance was recorded at $415 \mathrm{~nm}$ with the UNIQCAM 8625 UV/visible spectrophotometer. Quercetin equivalent was chosen as a standard. The amount of flavonoid was expressed as equivalent.

\section{RESULTS AND DISCUSSION}

The results of essential oil analysis of $R$. pedatus subp. pedatus is shown in Table-1. GC/MS analysis revealed 29 
components representing $99.1 \%$ of essential oil. Protoanemonin (14.3\%), phytol (13.7\%), (Z)-3-hexenal (7.8\%), octanal $(6.7 \%)$ and a sesquiterpenoid compound $\alpha$-bisabolol (7.9\%) were found to be the main components in the essential oil from the aerial parts of $R$. pedatus subsp. pedatus. Phytol, showing similarity to our results, was also previously found to be the main components of the essential oil of $R$. constantinapolitanus $(23.6 \%)$ and $R$. arvensis $(19.5 \%)^{32}$.

\begin{tabular}{ccc}
\multicolumn{3}{c}{ TABLE-1 } \\
\multicolumn{3}{c}{ CHEMICAL CONSTITUENTS OF ESSENTIAL } \\
OIL FROM R. pedatus subsp. pedatus \\
\hline RRI & Compounds & $\%$ \\
\hline 1048 & 2-Methyl-3-buten-2-ol & 1.2 \\
1093 & Hexanal & 2.9 \\
1225 & (Z)-3-Hexenal & 7.8 \\
1296 & Octanal & 6.7 \\
1304 & 1-Octen-3-one & 1.6 \\
1327 & (Z)-3-Hexenyl acetate & 1.3 \\
1391 & (Z)-3-Hexenol & 1.5 \\
1400 & Nonanal & 2.2 \\
1452 & 1-Octen-3-ol & 0.7 \\
1532 & Camphor & 1.5 \\
1541 & Benzaldehyde & 0.7 \\
1553 & Linalool & 1.2 \\
1596 & Protoanemonin* & 14.3 \\
1600 & Hexadecane & 0.5 \\
1663 & Phenylacetaldehyde & 2.1 \\
1726 & Germacrene D & 0.7 \\
1758 & (E,E)- $\alpha$-Farnesene & 0.7 \\
1765 & Geranayl acetate & 2.3 \\
1857 & Geraniol & 6.0 \\
1958 & (E)- $\beta$-Ionone & 2.3 \\
2041 & Pentadecanal & 3.3 \\
2131 & Hexahydrofarnesylacetone & 0.5 \\
2200 & Docosane & 0.8 \\
2242 & Methyl hexadecanate & 0.3 \\
2232 & $\alpha$-Bisabolol & 7.9 \\
2300 & Tricosane & 5.8 \\
2500 & Pentacosone & 5.0 \\
2622 & Phytol & 13.7 \\
2931 & Hexadecanoic acid & 3.6 \\
\hline Total & & 99.1 \\
\hline RRI: Relative retention indices calculated against n-alkanes, $\%$ \\
calculated from FID data, tr Trace (<0.1 \%), *Tentative identification
\end{tabular}

The fatty acid composition of $R$. pedatus subsp. pedatus is given in Table-2. Twenty seven fatty acids were identified by using GC and GC-MS. Linoleic acid (24.47\%) and palmitoleic acid $(18.94 \%)$ were found as main constituents of Ranunculus pedatus subsp. pedatus. Unsaturated fatty acids amounted to $60.43 \%$ of the total fatty acids, while the saturated fatty acids were $17.83 \%$. The presence of linoleic acid in adequate amounts is essential, because it is an essential fatty acid. Lack of dietary essential fatty acids such as linoleic acid has been implicated in aetiology of diseases including cardiovascular disease and its progression ${ }^{41}$. Linoleic acid can not be synthesized by the human body and is very important for the nutritional value of oils ${ }^{42}$.

The results of the cytotoxic activity are shown in Table-3. Ethanol and chloroform extracts of $R$. pedatus showed strong effect on HeLa with $\mathrm{IC}_{50}$ values of 47.97 and $78.48 \mu \mathrm{g} / \mathrm{mL}$, respectively In a previous report, Lorimer et $a l^{43}$ evaluated cytotoxic activity of ethanol extract of Ranunculus pinguis against P388 cell line. The extract of $R$. pinguis was shown to have strong inhibitory activity. They reported that the cytotoxic activity of $R$. pinguis against P388 cell line was due to the presence of a glucoside, ranunculin.

TABLE-2

FATTY ACID COMPOSITION OF R. pedatus subsp. pedatus (\%)

\begin{tabular}{|c|c|}
\hline Fatty acids & Content $(\%)$ \\
\hline C6:0 & $0.10 \pm 0.01^{\mathrm{a}}$ \\
\hline C8:0 & $0.06 \pm 0.02$ \\
\hline C10:0 & $0.09 \pm 0.01$ \\
\hline C11:0 & $0.09 \pm 0.02$ \\
\hline C13:0 & $0.11 \pm 0.01$ \\
\hline C15:0 & $0.26 \pm 0.03$ \\
\hline C16:0 & $2.78 \pm 0.02$ \\
\hline $\mathrm{C} 17: 0$ & $0.46 \pm 0.02$ \\
\hline C18:0 & $0.39 \pm 0.01$ \\
\hline C20:0 & $12.71 \pm 0.01$ \\
\hline $\mathrm{C} 21: 0$ & $0.19 \pm 0.03$ \\
\hline $\mathrm{C} 23: 0$ & $0.59 \pm 0.03$ \\
\hline$\Sigma \mathrm{SFA}^{\mathrm{b}}$ & $17.83 \pm 0.22$ \\
\hline $\mathrm{C} 14: 1 \omega 5$ & $0.80 \pm 0.02$ \\
\hline $\mathrm{C} 16: 1 \omega 7$ & $18.94 \pm 0.01$ \\
\hline $\mathrm{C} 17: 1$ & $0.41 \pm 0.02$ \\
\hline C18:1t & $3.96 \pm 0.01$ \\
\hline C $18: 1 \omega 9$ & $1.01 \pm 0.01$ \\
\hline C20:1 & $0.27 \pm 0.03$ \\
\hline $\mathrm{C} 24: 1 \omega 9$ & $0.36 \pm 0.01$ \\
\hline$\Sigma \Sigma_{U F A}{ }^{b}$ & $25.75 \pm 0.11$ \\
\hline $\mathrm{C} 18: 2 \mathrm{n} 6 \mathrm{t}$ & $5.41 \pm 0.05$ \\
\hline $\mathrm{C} 18: 2 \omega 6$ & $24.47 \pm 0.02$ \\
\hline $\mathrm{C} 20: 2 \omega 6$ & $0.13 \pm 0.01$ \\
\hline C22:2 & $0.06 \pm 0.02$ \\
\hline $\mathrm{C} 18: 3 \omega 6$ & $1.25 \pm 0.01$ \\
\hline $\mathrm{C} 20: 3 \omega 6$ & $1.43 \pm 0.01$ \\
\hline $\mathrm{C} 20: 4 \omega 6$ & $0.17 \pm 0.02$ \\
\hline $\mathrm{C} 20: 5 \omega 5$ & $1.76 \pm 0.01$ \\
\hline $\boldsymbol{\Sigma P U F A}^{\mathrm{b}}$ & $34.68 \pm 0.15$ \\
\hline $\begin{array}{l}\text { aAverage of three } \\
\text { SFA: Saturated fa } \\
\text { PUFA: Polyunsat }\end{array}$ & $\begin{array}{l}\mathrm{d} \text { are means } \pm \\
\text { urated fatty aci }\end{array}$ \\
\hline
\end{tabular}

\begin{tabular}{cccc}
\multicolumn{4}{c}{ TABLE-3 } \\
CYTOTOXIC ACTIVITY RESULTS OF EXTRACTS \\
OF R. pedatus subsp. pedatus \\
\hline Extract & $\mathrm{IC}_{50}(\mu \mathrm{g} / \mathrm{mL})^{\mathrm{a}}$ & $\mathrm{IC}_{50}(\mu \mathrm{g} / \mathrm{mL})^{*}$ & $\mathrm{IC}_{50}(\mu \mathrm{g} / \mathrm{mL})^{*}$ \\
& $\mathrm{Pc} 3$ & $\mathrm{HeLa}$ & Vero \\
\hline Chloroform & 78.48 & $\mathrm{NA}^{\mathrm{b}}$ & $\mathrm{NA}$ \\
Ethanol & 47.97 & 174.04 & 144.62 \\
\hline${ }^{a}$ Values are mean triplicate analysis, ${ }^{b} \mathrm{NA}$ : Not active
\end{tabular}

The presence of flavonoids (quercetin, kaempherol, vitexin, isovitexin, orientin and isoorientin) $)^{11-15}$, alkaloids (berberine, palmatine, columbamine and magnoflorine $)^{18,19}$ and triterpenes (ursolic acid, oleanolic acid and betulinic acid) ${ }^{16}$ were previously reported by phytochemical studies on various species of Ranunculus. Vitexin, isovitexin, $p$-hydroxy benzoic acid and $p$-coumaric acid from $R$. pedatus subsp. pedatus were isolated and reported in our previous work. The cytotoxic activities of the fractions were also evaluated by the brine shrimp lethality bioassay. The moderate cytotoxic activity was attributed to presence of vitexin and isovitexin ${ }^{15}$ which were previously found to be cytotoxic ${ }^{44}$. Cytotoxic effect of berberine was also 
determined against human tumor cell lines ${ }^{45}$. Ursolic acid was shown to have moderate cytotoxicity against human cancer lines $^{46}$. Vitexin, isovitexin, ursolic acid and berberine might be responsible for the observed cytotoxic activities of investigated extracts.

The antioxidant activity of the ethanol and chloroform extracts of $R$. pedatus were reported in Table-4. The ethanol extract showed $67.54 \%$ DPPH inhibition. A positive correlation between flavonoid and total phenolic contents of the extracts and the antioxidant activity was observed. The TPC of the ethanol and chloroform extracts of $R$. pedatus subsp. pedatus were determined as 118.4 and 472.06, gallic acid equivalents $(\mathrm{mg} / \mathrm{g})$ dry matter. TFC of the ethanol extract of $R$. pedatus subsp. pedatus was obtained as $4.36 \%$, whereas chloroform extract had only $1.23 \%$. Typical phenolics that possess antioxidant activity have been characterized as flavonoids and phenolic acids ${ }^{47}$. Phenols and polyphenols known as chain-breaking antioxidants are very important constituents of plants ${ }^{48}$. Many flavonoids were isolated in some Ranunculus species in previous studies ${ }^{12-15}$. Vitexin and isovitexin were reported to have antioxidant activity in a previous study ${ }^{49}$. Vitexin and isovitexin could be responsible for antioxidant activity observed for the ethanol extract of $R$. pedatus subsp. pedatus. Kaya et al. studied the flavonoid and phenolic content and antioxidant activities of hexane, ethyl acetate, methanol and water extracts of $R$. marginatus var. trachycarpus and $R$. sprunerianus and highest antioxidant activity was observed for methanol extracts of the plant ${ }^{24}$. In addition, the antioxidant activity of aqueous methanolic extract of $R$. repens flowers and leaves were $0.12 \mathrm{mM} \mathrm{TE} / \mathrm{g}$ and $0.13 \mathrm{mM} \mathrm{TE} / \mathrm{g}$, respectively $^{27}$.

\begin{tabular}{|c|c|c|c|}
\hline \multicolumn{4}{|c|}{$\begin{array}{c}\text { TABLE-4 } \\
\text { DETERMINATION OF ANTIOXIDANT ACTIVITY, } \\
\text { TOTAL PHENOLIC AND FLAVONOID CONTENT } \\
\text { OF } R \text {. pedatus subsp. pedatus }\end{array}$} \\
\hline Extract & DPPH (\%) & TPC $(\mathrm{mg} / \mathrm{g})^{\mathrm{a}}$ & TFC $(\mathrm{g} \%)^{\mathrm{b}}$ \\
\hline Chloroform & $31.82 \pm 4.04^{\circ}$ & $118.4 \pm 5.74$ & $1.233 \pm 0.05$ \\
\hline Ethanol & $67.54 \pm 5.49$ & $472.06 \pm 3.72$ & $4.368 \pm 0.12$ \\
\hline
\end{tabular}

\section{Conclusion}

In conclusion, this is the first report on the fatty acid and essential oil composition and the cytotoxic and antioxidant activities of $R$. pedatus subsp. pedatus from Turkey ${ }^{29}$. Components were identified in the essential oil and the main components were phytol and protoanemonin. The main constituents of fatty acid of $R$. pedatus subsp. pedatus were linoleic and palmitoleic acid. It is clear that, there is a significant correlation between the total phenolic and flavonoid content and antioxidant activity. Further studies are required for the isolation and structure elucidation of individual compounds responsible for the observed biological activities.

\section{ACKNOWLEDGEMENTS}

The authors wish to thanks Ege University Faculty of Pharmacy Pharmaceutical Sciences Research Centre (FABAL, Izmir, Turkey)for fatty acid analysis and cytotoxic activities.
This research was supported by Ege University Research Fund (No.12/ECZ/013), Izmir, Turkey

\section{REFERENCES}

1. M. Tamura, in ed.: P. Hiepko, Angiospermae Ordnung Ranunculales. Fam. Ranunculaceae. II. Systematic part. In: Natürliche Pflanzenfamilien, Duncker and Humbolt, Berlin, edn 2, pp. 223 (1995).

2. P.H. Davis, in ed.: P.H. Davis, Flora of Turkey, Edinburgh University Press, Edinburg, pp. 146 (1965)

3. P.H. Davis, in eds.: P.H. Davis, R.R. Mill and K. Tan, Flora of Turkey, Edinburgh University Press, Edinburg, pp. 19, 231 (1988).

4. E. Ugurlu and Ö. Seçmen, Fitoterapia, 79, 126 (2008).

5. G. Gürhan and N. Ezer, J. Fac. Pharm. Hacettepe, 24, 37 (2004).

6. C.A. Newall, L.A. Anderson and J.D. Phillipson, Herbal Medicines, Pharmaceutical Press, London, pp. 209 (1996).

7. N.G. Passalacqua, P.M. Guarrera and G. De Fine, Fitoterapia, 78, 52 (2007).

8. G. Honda, E. Yesilada, M. Tabata, E. Sezik, T. Fujita, Y. Takeda, Y. Takaishi and T. Tanaka, J. Ethnopharmacol., 53, 75 (1996).

9. E. Sezik, E. Yesilada, G. Honda, Y. Takaishi, Y. Takeda and T. Tanaka, J. Ethnopharmacol., 75, 95 (2001).

10. T. Baytop, Theraphy with Medicinal Plants in Turkey (Past and Present), 2nd ed., Nobel tip Kitabeveri, Istanbul, pp. 375 (1999).

11. S.D. Webster, Aquat. Bot., 40, 11 (1991).

12. J.L. Fiasson, K. Gluchoff-Fiasson and G. Dahlgren, Biochem. Syst. Ecol., 25, 327 (1997).

13. K.R. Markham, K.A. Mitchell and M. Campos, Phytochemistry, 45, 203 (1997)

14. J.M. Prieto, M.C. Recio, R.M. Giner, S. Máñez and J.L. Rios, J. Ethnopharmacol., 89, 131 (2003).

15. T. Erdogan, B. Kivcak, M.A. Onur and A. Braca, Chem. Nat. Prod., 3, 437 (2012).

16. C. Wegner, M. Hamburger, O. Kunert and E. Haslinger, Helv. Chim. Acta, 83, 1454 (2000).

17. Y. Zhao, J.-L. Ruan, J.-H. Wang, Y. Cong, S. Song, Y.-L. Cai, W. Fang and D.-N. Zhou, Nat. Prod. Res., 22, 233 (2008).

18. A. Bonora, A. Tosi, G. Dallolio and A. Bruni, Phytochemistry, 29, 2389 (1990).

19. L. Zhang, Z. Yang and J.K. Tian, Chem. Pharm. Bull. (Tokyo), 55, 1267 (2007).

20. J. Chen, C. Yao and L.M. Xia, Spectrosc. Spect. Anal., 26, 1550 (2006).

21. J.K. Tian, F. Sun and Y. Cheng, J. Asian Nat. Prod. Res., 8, 35 (2006).

22. Y. Zou, C. Tan, B. Wang, S. Jiang and D. Zhu, Chem. Nat. Compd., 46, 19 (2010).

23. E.K. Barbour, M. Al Sharif, V.K. Sagherian, A.N. Habre, R.S. Talhouk and S.N. Talhouk, J. Ethnopharmacol., 93, 1 (2004).

24. G.I. Kaya, N.U. Somer, S. Konyalioglu, H. Yalçin, U. Yavasoglu, B. Sarikaya and M.A. Onur, Turk. J. Biol., 34, 1 (2010).

25. S. Bissa and A. Bohra, Botany Res. Int., 5, 10 (2012).

26. M.J. Cuellar, R.M. Giner, R.M. Recio, M.C. Just, S. Manez, S. Cerda and J.L. Rios, Phytother. Res., 12, 18 (1998).

27. D. Mantle, F. Eddeb and A.T. Pickering, J. Ethnopharmacol., 72, 47 (2000).

28. E. Küpeli Akkol, I. Süntar, T. Fafal Erdogan, H. Keles, T. Mert Gonenç and B. Kivçak, J. Ethnopharmacol., 139, 478 (2012).

29. M.P. Kähkönen, A.I. Hopia, H.J. Vuorela, J.-P. Rauha, K. Pihlaja, T.S. Kujala and M. Heinonen, J. Agric. Food Chem., 47, 3954 (1999).

30. D. Mantle, M.A. Gok and T.W. Lennard, Adverse Drug React. Toxicol. Rev., 20, 89 (2001).

31. I. Orhan, B. Sener, T. Atici, R. Brun, R. Perozzo and D. Tasdemir, Phytomedicine, 13, 388 (2006).

32. S. Terzioglu, A. Yasar, N. Yayli, N. Yilmaz, S. Karaoglu and N. Yayli, Asian J. Chem., 20, 3277 (2008).

33. IUPAC Standards methods for analysis of oils, fats and derivatives (6th edition), Pergamon Press, Oxford, pp. 59-66 (1979).

34. F.W. McLafferty and D.B. Stauffer, The Wiley/NBS Registry of Mass Spectral Data, John Wiley and Sons, New York (1989)..

35. W.A. Koenig, D. Joulain and D.H. Hochmuth, in ed.: D.H. Hochmuth, Terpenoids and Related Constituents of Essential Oils, Mass Finder 3, Convenient and Rapid Analysis of GC/MS, Hamburg, Germany (2004). 
36. D. Joulain and W.A. Koenig, The Atlas of Spectra Data of Sesquiterpene Hydrocarbons, EB-Verlag, Hamburg (1998).

37. ESO, The Complete Database of Essential Oils, Boelens Aroma Chemical Information Service, The Netherlands (1989).

38. A. Meda, C.E. Lamien, M. Romito, J. Millogo and O.G. Nacoulma, Food Chem., 91, 571 (2005).

39. C.C. Chang, M.H. Yang, H.M. Wen and J.C. Chern, J. Food Drug Anal., 10, 178 (2002).

40. R.G. Woisky and A. Salatino, J. Agric. Res., 37, 99 (1998).

41. P. Parikh, M.C. McDaniel, M.D. Ashen, J.I. Miller, M. Sorrentino, V. Chan, R.S. Blumenthal and L.S. Sperling, J. Am. Coll. Cardiol., 45, 1379 (2005).

42. J.E. Brown, Eur. J. Lipid Sci. Technol., 107, 119 (2005).

43. S.D. Lorimer, G. Barns, A.C. Evans, L.M. Foster, B.C.H. May, N.B.
Perry and R.S. Tangney, Phytomedicine, 2, 317 (1996).

44. M.M. Hernández, C. Heraso, M.L. Villarreal, I. Vargas-Arispuro and E. Aranda, J. Ethnopharmacol., 67, 37 (1999).

45. C.P. Cordero, S. Gomez-Gonzalez, C.J. Leon-Acosta, S.J. MorantesMedina and F.A. Aristizabal, Fitoterapia, 75, 225 (2004).

46. B.S. Min, Y.H. Kim, S.M. Lee, H.J. Jung, J.S. Lee, M.K. Na, C.O. Lee, J.P. Lee and K. Bae, Arch. Pharm. Res., 23, 155 (2000).

47. V. Bohm, N.L. Puspitasari-Nienaber, M.G. Ferruzzi and S.J. Schwartz, J. Agric. Food Chem., 50, 221 (2002).

48. F. Shahidi, P.K. Janitha and P.D. Wanasundara, Crit. Rev. Food Sci. Nutr., 32, 67 (1992).

49. M. Shibano, K. Kakutani, M. Taniguchi, M. Yasuda and K. Baba, J. Nat. Med., 62, 349 (2008). 